\title{
KAJIAN ESTETIKA FOTOGRAFI DJAJA TJANDRA KIRANA
}

\author{
Zahrawani, Hardiman, I Gusti Made Budiarta \\ Jurusan Pendidikan Seni Rupa \\ Fakultas Bahasa dan Seni \\ Universitas Pendidikan Ganesha \\ Singaraja, Indonesia \\ e-mail: zahrawani01@gmail.com, hardiman_art@yahoo.com, \\ gustiarta97@yahoo.com
}

\begin{abstract}
Abstrak
Penelitian tentang fotografi ini memfokuskan kajiannya pada fotografi karya Djaja Tjandra Kirana yang dihimpun dalam buku Jiwa Cahaya, bertujuan: (1) untuk mendeskripsikan jenis -jenis fotografi Djaja Tjandra Kirana, (2) untuk mendeskripsikan nilai estetika dalam karya fotografi Djaja Tjandra Kirana. Penelitian ini merupakan penelitian deskriptif kualitatif. Teknik pengumpulan data yang digunakan adalah teknik dokumentasi, kepustakaan dan triangulasi.

Hasil penelitian menunjukkan bahwa: (1) Jenis-jenis fotografi Djaja Tjandra Kirana adalah: fotografi kehidupan manusia (human interest), fotografi jurnalistik (photojournalism), fotografi pemandangan (landscape photography), fotografi model (photography modelling), fotografi jalanan (street photography), dan fotografi potret (portrait photography) dan (2) Nilai estetika fotografi Djaja Tjandra Kirana adalah: unsur-unsur rupa (unsur desain) terdiri dari enam unsur yaitu: garis, shape (bangun), tekstur, warna, intensity/chroma, ruang dan waktu; Dasar-dasar penyusunan (prinsip desain) terdiri dari empat unsur yaitu, paduan harmoni, paduan kontras, paduan irama, dan paduan gradasi; dan hukum penyusunan (azas desain) terdiri dari empat unsur yaitu, asas kesatuan, keseimbangan, kesederhanaan (simplicity), aksentuasi (emphasis), dan proporsi.
\end{abstract}

Kata kunci: Estetika, Fotografi, Djaja Tjandra Kirana.

\begin{abstract}
Research on photography focuses this study on the photography of Djaja Tjandra Kirana compiled in aJiwa Cahaya book, aim (2) to describe the aesthetic values conveyed in Djaja Tjandra Kirana's photographical work. This was a descriptive qualitative study. The data were collected with documentation, library research, and triangulation techniques.

The result showed that (1) the types of Djaja Tjandra Kirana's photography were: the photography of human interest, photojournalism, landscape photography, photography modelling, street photography, and portrait photography. The result also showed that (2) the aesthetical values conveyed in Djaja Tjandra Kirana's photography were: the design element, which was divided into six elements, namely line, shape, texture, color, intensity/chroma, space and time, and also the design principle, which was divided into four composite elements, namely the composite of harmony, contrast, rhythm, and gradation. Another value found was also the design basis, which was divided into four principles, namely the principle of unity, balance, simplicity, emphasis, and proportion.
\end{abstract}

Keywords: Aesthetic, Photography, Djaja Tjandra Kirana 


\section{PENDAHULUAN}

"Fotografi (photography) berasal dari bahasa Yunani, dari kata photos berarti cahaya dan graphein berarti menggambar/melukis. Fotografi secara umum adalah proses melukis atau menggambar yang menghasilkan foto atau gambar dengan bantuan cahaya. Alat yang digunakan adalah kamera" (Andi, 2005: 1).

Dalam dunia fotografi ditemukan pada tahun $1841 \mathrm{Dr}$. Jurriaan Munnich datang ke Indonesia. Sejarah fotografi Indonesia tidak lepas dari nama Kassian Cephas. Seorang fotografer Jawa tulen, kelahiran tanggal 15 Februari 1844. Nama Kassian Cephas mulai diketahui dengan karya fotografi tertua buatannya tahun 1875.

Fotografi dari era Hindia Belanda hingga tahun 80 an belum mengalami perkembangan berarti, pemanfaatan foto untuk kepentingan citra-citra kepariwisataan Bali masih mendominasi seperti jasa pemotretan di studio dan objek wisata, untuk postcard, buku, majalah dan brosur panduan wisata. Pemanfaatan fotografi lainnya yaitu untuk kepentingan media seiring dengan mulai berkembangnya industri media di Bali sekitar tahun 1950. Pada tahun 1982 beberapa fotografer yang berdomisili di Bali mulai mempelopori te rbentuknya sebuah wadah berkumpul yang disebut Perhimpunan Fotografer Bali (PFB). Resmi terbentuk tahun 1983.

Perkembangan fotografi di Bali beberapa tahun terakhir ini menunjukkan suatu kemajuan yang pesat, hal ini bisa dilihat dari semakin banyaknya even fotografi dan tumbuhnya komunitas fotografi. Sebagai gambaran, klub foto yang dulunya hanya satu di era tahun 80 an kemudiaan berkembang pesat menjadi sekitar 10 komunitas hingga awal tahun 2010. Beberapa diantaranya bahkan tercatat beranggotakan hingga seratusan orang. Klub-klub tersebut umumnya terbentuk setelah booming fotografi digital dan maraknya komunitas fotografi dunia maya semenjak tahun 2000.

Salah seorang fotografer di Bali adalah Djaja Tjandra Kirana. la mulai menekuni dunia fotografi sedari usia 15 tahun dengan menggunakan kamera box secara otodidak, ia mempelajari fotografi di Semarang, Jawa Tengah. Djaja Tjandra Kirana tak kunjung putus untuk berkarya. Setelah hampir 50 tahun menggeluti dunia fotografi. Fotografer kelahiran Denpasar tah un 1944 ini masih terus menempuh jalan berkesenian dan tetap melakukan eksperimen dan eksplorasi teknik dan media fotografi. Djaja Tjandra Kirana memutuskan untuk terjun ke dunia fotografi pada tahun 1963. Tahun 1976 ia merupakan salah seorang pendiri sebuah perkumpulan fotografi di Semarang, yaitu Semarang Foto Club (SPC). Tidak berhenti sampai disana ia bersama beberapa fotografer di Bali mulai mempelopori terbentuknya Perhimpunan Fotografer Bali (PFB) pada tahun 1983. Hasil-hasil karya Djaja Tjandra Kirana tidak hanya fotografi namun ada juga karya lukis yang mengangkat tema Bali.

Seniman fotografi penganut paham estetika salonfoto ini menekuni beberapa jenis fotografi diantaranya: fotografi kehidupan manusia, fotografi pemandangan, fotografi potret, fotografi komersial, dan fotografi perikahan.

Sebagaimana yang telah dijabarkan di atas, maka permasalahan yang dapat dirumuskan dalam penelitian ini antara lain: (1) Apa sajakah jenis fotografi Djaja Tjandra Kirana? dan

(2) Bagaimana nilai estetika fotografi Djaja Tjandra Kirana?

Berdasarkan rumusan masalah, tujuan yang dapat dicapai sebagai berikut: (1) Untuk mendeskripsikan jenis fotografi Djaja Tjandra Kirana dan (2) Untuk mendeskripsikan nilai estetika fotografi Djaja Tjandra Kirana.

Adapun manfaat yang diharapkan dari penelitian ini yaitu manfaat akademis, teoritis, dan praktis. Manfaat akademis, sebagai seorang mahasiswa, penelitian ini sangat bermanfaat untuk 
meningkatkan wawasan serta pengetahuan bagi penulis dalam bidang fofografi. Manfaat teoritis, diharapkan dengan penelitian ini dapat memberikan referensi atau pengetahuan bagi penelitian sejenis khususnya dalam pengkajian estetika fotografi. Dan manfaat praktis, hasil penelitian ini, diharapkan dapat memberikan pengetahuan bagi masyarakat umum dalam bidang fotografi. Sedangkan bagi para pembaca sebagai informasi dalam pengkajian estetika fotografi.

\section{METODE PENELITIAN}

Penelitian ini adalah penelitian bentuk deskriptif yang bersifat kualitatif. Teknik pengumpulan data pada penelitian ini menggunakan teknik dokumentasi, teknik kepustakaan, dan teknik triangulasi.

Dalam penelitian ini menggunakan teknik analisis model Miles dan Huberman, dengan prosedur yaitu, Reduksi Data (Data Reduction), Penyajian Data (Data Display), dan verifikasi (Conclusion drawing/verification).

\section{HASIL DAN PEMBAHASAN}

\section{Jenis Fotografi Djaja Tjandra Kirana}

Jenis-jenis fotografi Djaja Tjandra Kirana yang terdapat dalam buku "Jiwa Cahaya" adalah sebagai berikut: fotografi kehidupan manusia (Human Interest), fotografi jurnalistik (Photojournalism), fotografi pemandangan (Landscape Photography), fotografi model (Photography Modelling), fotografi jalanan (Street Photography), dan fotografi potret (Portrait Photography).

\section{(1) Human Interest (fotografi kehidupan manusia)}

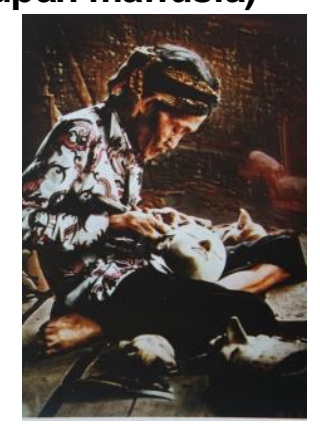

Gambar 1 "Tangguh sampai tua" (1977) (Sumber: Jiwa Cahaya)

Dalam foto dengan judul "Tangguh Sampai Tua", terdiri dari objek seorang kakek mengenakan ikat kepala batik dan baju batik. Ikat kepala batik dan baju batik ini adalah penanda bahwa kakek ini orang jawa. Sambil duduk bersila kakek ini membuat topeng kayu. Di latar depan kelihatan bilah-bilah papan tempat duduknya si kakek, dan di latar belakang tampak dinding bedek. Bilah-bilah papan dan dinding bedek adalah sebuah setting yang menunjukkan bahwa si kakek bekerja atau tinggal di desa.

Foto ini diambil dari samping objek dengan sumber cahaya dari samping kanan, depan objek dan dari belakang (backlight). Pencahayaan ini membantu menegaskan ekspresi si kakek sekaligus juga membantu menggambarkan lingkungan si kakek. Dengan demikian jelas bahwa foto dengan objek kakek sedang membuat topeng dengan setting pedesaan ini dapat dikategorikan sebagai fotografi human interest. Seperti yang dijelaskan oleh Dharmawan (t.t.) bahwa fotografi human interest adalah fotografi yang menggambarkan manusia dan aktivitasnya. 
(2) Photojournalism (fotografi jurnalistik)

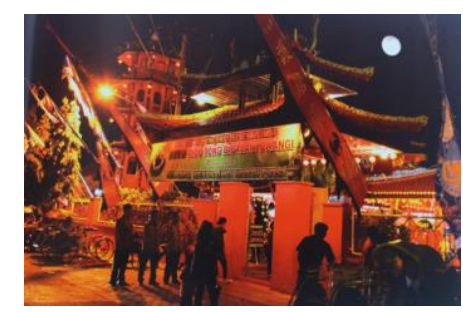

Gambar 2 "Kebahagiaan Umat" (2009)

(Sumber: Jiwa Cahaya)

Foto dengan judul "Kebahagiaan Umat" (2009) tampak di sini sejumlah orang sedang melakukan aktivitas di sebuah klenteng pada malam hari di pintu bagian depan klenteng ini terdapat beberapa buah bandir dan umbul-umbul yang menandakan bahwa pada saat itu sedang berlangsung suatu perayaan. Di bagian depan klenteng terdapat juga spanduk bertuliskan "segenap pengurus beserta umat TITD 'ho tong bio' Banyuwangi Mengucapkan Selamat Menunaikan Ibadah Puasa".

Foto ini memiliki unsur $5 \mathrm{~W}+1 \mathrm{H}$, yaitu what (apa), where (dimana), who (siapa), when (kapan), why (mengapa) dan how (bagaimana), yaitu what (apa): sedang berlangsungnya perayaan, where (dimana): di klenteng, who (siapa): oleh umat TITD "ho tong bio" Banyuwangi, when (kapan): pada malam hari dan menjelang bulan puasa, why (mengapa): untuk menegaskan bagaimana orang-orang penganut agama konguchu memilki toleransi melalui ucapan selamat berpuasa dan how (bagaimana): melalui spanduk yang dipasang di depan klenteng.

Tegasnya foto ini menggambarkan sejumlah orang di depan klenteng sedang melakukan aktivitas malam hari yang menunjukkan waktu berdekatan dengan bulan ramadhan yang ditunjukkan dengan spanduk ucapan selamat menunaikan ibadah puasa. Foto ini juga menegaskan bagaimana orang-orang penganut agama konguchu memilki toleransi melalui ucapan selamat berpuasa yang diperlihatkannya melalui spanduk yang dipasang di depan klenteng.

Dari deskripsi di atas jelas bahwa foto dengan judul "Kebahagiaan Umat" ini memiliki unsur $5 \mathrm{~W}+1 \mathrm{H}$, maka foto ini dapat dikategorikan sebagai foto jurnalistik. Hal ini seperti ditegaskan oleh Dharmawan (t.t.), bahwa fotografi jurnalistik adalah fotografi yang menceritakan sebuah kisah yang memiliki unsur berita.

(3) Landscape Photography (fotografi pemandangan)

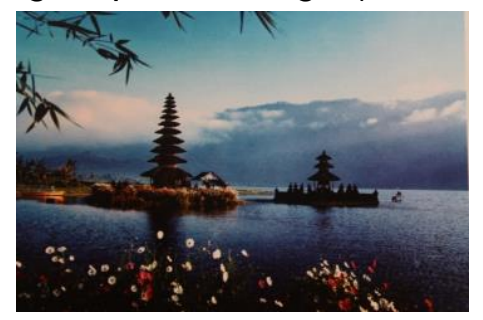

Gambar 3 "Pagi di Ulun Danu” (1983)

(Sumber: Jiwa Cahaya)

Gambar 3 dengan judul "Pagi di Ulun Danu" memperlihatkan objek foto pegunungan, dua buah pura, danau dan tumbuhan. Seperti yang telihat danau dengan air yang berwarna biru tua, dan terdapat pura di atasnya. Pada latar depan terlihat bunga dan ranting pohon. Bunga dan ranting pohon tersebut dijadikan sebagai latar depan yang hampir menyerupai framing. Sedangkan latar belakang menampilkan langit berwarna biru muda menunjukkan cuaca sedang cerah dan 
pegunungan yang tertutup gumpalan kabut. Gambar ini dilihat dari objek yang ditampilkannya, jelas termasuk fotografi pemandangan daratan, sebab seperti yang dijelaskan Abdi (2012), fotografi pemandangan daratan adalah foto yang mencakup alam pegunungan, lembah, persawahan dan lain-lain.

(4) Photography Modelling (fotografi model)

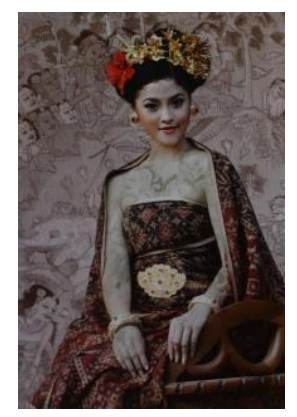

Gambar 4 "Made Ayu" (2011)

(Sumber: Jiwa Cahaya)

Pada gambar 4 "Made Ayu" terlihat seorang perempuan tersenyum menghadap ke kamera, duduk di kursi dengan anggun memakai pakaian adat kemben serta selendang yang dipakai di pundak, kedua tangan yang berada di atas paha, dan mengenakan aksesoris yang berupa gelang, anting-anting, bros, dan bunga emas sebagai hiasan kepala. Latar belakang yang ada pada foto tersebut terlihat lukisan tradisi. Foto ini tergolong dalam jenis fotografi model karena sudah memperlihatkan ciri fotografi model yaitu pose seorang perempuan dengan memperlihatkan ekspresi tersenyum. (Agnes, 2014).

(5) Street Photography (fotografi jalanan)

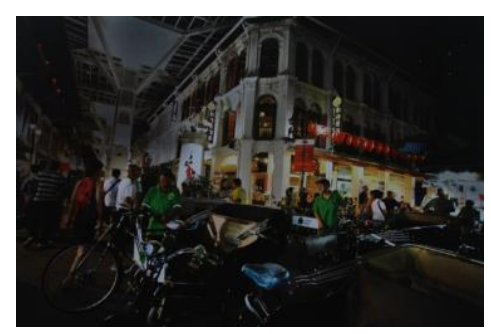

Gambar 5 "Malam di China Town"(2014)

(Sumber: Jiwa Cahaya)

Foto dengan judul "Malam di China Town" ini memperlihatkan aktivitas masyarakat pada malam hari di pusat perbelanjaan yang terlihat ramai oleh pengunjung, terlihat juga tukang becak sedang menunggu penumpang. Latar belakang pada foto ini memperlihatkan adanya bangunan tinggi berwarna putih. Foto ini dapat digolongkan dalam jenis fotografi jalanan. Menurut Dharmawan (t.t.), fotografi jalanan adalah salah satu jenis fotografi yang digunakan un tuk merekam kegiatan sehari-hari pada kehidupan manusia di jalanan atau ruang publik, sehingga hasilnya adalah cerminan dari masyarakat. 
(6) Portrait Photography (fotografi potret)

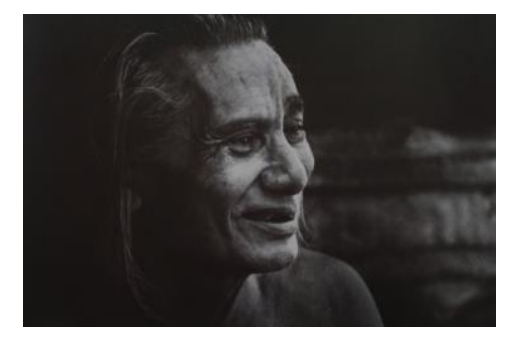

Gambar 6 "Ida Bagus Made" (1984)

(Sumber: Jiwa Cahaya)

Karya ini memperlihatkan personalitas Ida Bagus Made dengan pose menghadap ke samping sambil tersenyum. Ida Bagus Made adalah seorang pelukis yang lahir pada tahun $1915 \mathrm{di}$ Banjar Tebesaya, Ubud, Bali. la adalah penerima hadiah seni Wija Kusuma dan Dharma Kusuma dari Pemerintah Daerah Bali. Popularitasnya muncul bukan hanya karena karya-karyanya yang menyimpan mutu tinggi. Tapi juga karena peri kehidupannya yang eksentrik, keras hati serta sangat menghormati benar karya-karyanya.

Berdasarkan deskripsi di atas yang menggambarkan siapa tokoh (objek) yang di foto jelas karya foto ini tergolong dalam fotografi potret. (Muchtar, 2013)

\section{Nilai Estetika Fotografi Djaja Tjandra Kirana}

\section{a. Unsur-unsur Rupa (Unsur Desain)}

Unsur-unsur rupa (unsur desain) unsur-unsur yang menciptakan suatu karya seni rupa yang dibagi menjadi enam unsur, yaitu, garis, shape (bangun), tekstur, warna, intensity/chroma, ruang dan waktu.

\section{Unsur Garis}

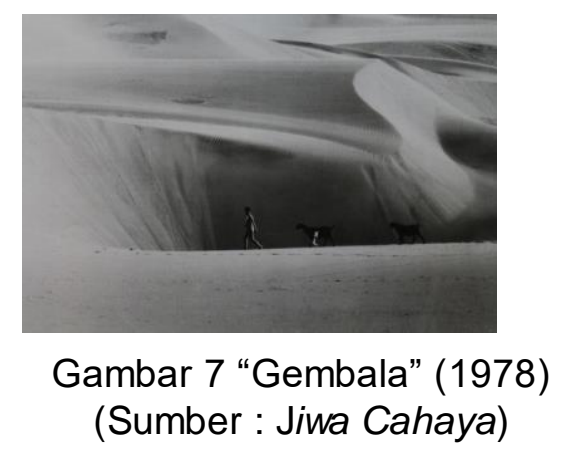

Gambar 7 yang berjudul "Gembala", tergolong banyak memiliki unsur garis karena terlihat bahwa adanya garis pada sisi padang pasir. Pada latar depan terlihat garis horizon. Sedangkan pada latar belakang terlihat garis lengkung pada padang pasir yang melintang dari kiri sampai ke kanan. Unsur garis dalam karya ini termasuk garis non formal karena garis-garis dalam foto di atas terlihat gemulai dan lembut. (Kartika, 2004) 
2. Unsur Shape (Bangun)

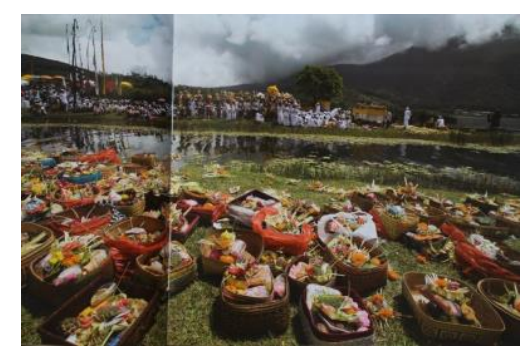

Gambar 8 “Odalan di Danau Beratan” (2008)

(Sumber : Jiwa Cahaya)

Foto di atas dengan judul "Odalan di Danau Beratan" tergolong dalam unsur shape (bangun). Karena dalam foto tersebut memperlihatkan adanya perubahan bentuk objek karena distorsi. Objek ini diambil dengan lensa wide angle sekitar $35 \mathrm{~mm}$ di bawah lensa standar, yang memungkinkan terjadinya distorsi pada objek.

Menurut Kartika (2004) bahwa shape adalah suatu bidang yang dibatasi oleh kontur. Unsur shape digunakan sebagai symbol oleh perasaan seniman karena unsur shape mengalami perubahan wujud.

3. Unsur Texture (rasa permukaan bahan)

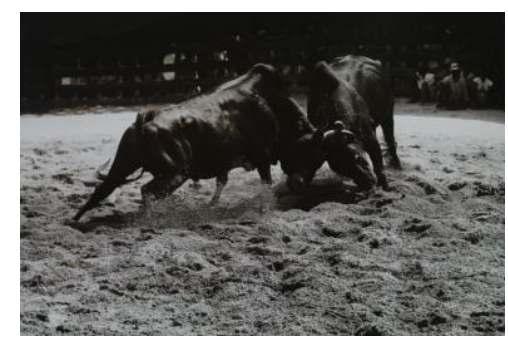

Gambar 9 "Adu Kekuatan” (2014)

(Sumber : Jiwa Cahaya)

Foto di atas menunjukkan adanya unsur tekstur semu karena dalam foto hanya bisa dilihat atau dirasakan yaitu terlihat dengan jelas rasa permukaan tanah tersebut kasar pada tanah yang digunakan sebagai arena pertandingan. Gambar 9 dengan judul "Adu Kekuatan" tersebut termasuk dalam unsur tekstur. (Kartika, 2004)

4. Unsur Warna

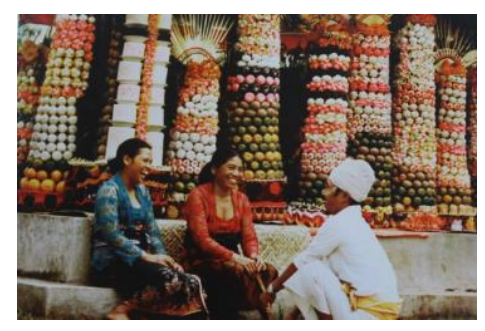

Gambar 10 “Kepalang Riang Tak Kepalang” (1984)

(Sumber : Jiwa Cahaya)

Karya di atas tergolong dalam foto yang mengutamakan unsur warna karena gambar tersebut memperlihatkan adanya full colour pada pajegan, yaitu warna-warna buah misalnya, 
warna kuning, hijau, merah, merah muda. Selain itu, warna biru dan merah pada kebaya yang dikenakan dua perempuan serta warna putih pada pakaian yang dikenakan laki-laki. Perpaduan warna kontras warna pakaian yang digunakan oleh dua orang perempuan tersebut dan warna warna buah yang ada pada pajegan. Kartika (2004)

\section{Intensity/Chroma}

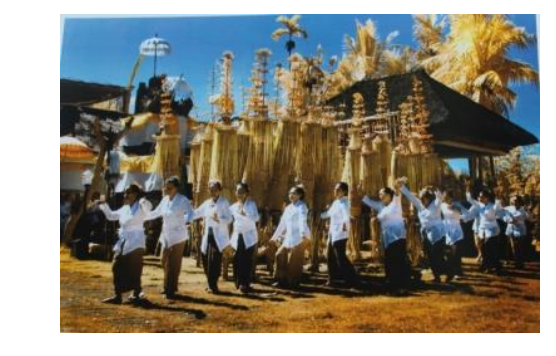

\section{Gambar 11"Rejang Pejeng” (2007)}

(Sumber : Jiwa Cahaya)

Pada foto yang berjudul "Rejang Pejeng" dibuat dengan kamera infrared, terlihat bahwa intensitas warna pada karya ini tinggi, sehingga menghasilkan foto yang cerah dari warna daun kelapa berwarna kuning mencolok dan warna putih pada pakaian, disebabkan karena intensitas warna yang tinggi. Semakin besar intensitasnya maka efek warna yang diberikan semakin terlihat. Intensitas warna pada karya ini tinggi, sehingga menghasilkan foto yang cerah. Sebagaimana dijelaskan Kartika (2004) bahwa intensity/chroma adalah perihal kuat atau lemahnya intensitas warna.

6. Ruang dan Waktu

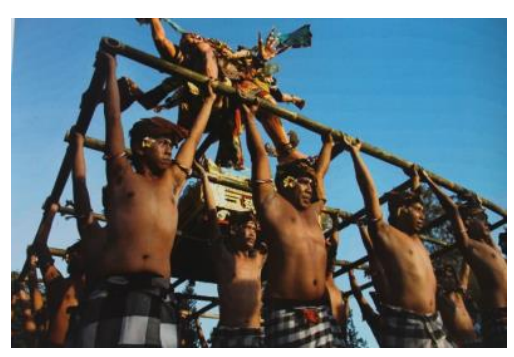

Gambar 12 “Mengarak Ogoh-ogoh” (2010)

(Sumber : Jiwa Cahaya)

Gambar 12 yang berjudul "Mengarak Ogoh-ogoh" digolongkan dalam foto yang memiliki unsur ruang dan waktu karena pada karya tersebut memperlihatkan adanya perspekstif. Bambu bambu yang berderet menuju satu titik lenyap, orang-orang semakin ke belakang semakin kecil ukurannya. Perspektif tersebut menimbulkan adanya kesan ruang (kedalaman). (Kartika, 2004)

\section{b. Dasar-dasar Penyusunan (Prinsip Desain)}

penyusunan atau komposisi dari unsur-unsur estetik merupakan prinsip pengorganisasian unsure dalam desain. Dasar-dasar penyusunan (prinsip desain) dibagi menjadi empat unsur yaitu, paduan harmoni, paduan kontras, paduan irama, dan paduan gradasi. 
1. Paduan Harmoni (selaras)

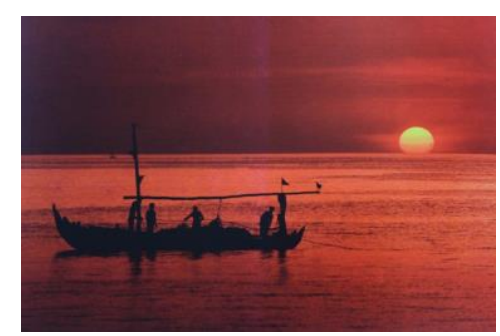

Gambar 13“Merah Senja” (1984)

(Sumber : Jiwa Cahaya)

Karya ini menampilkan adanya unsur harmoni karena warnanya seperti senada tidak kontras, warna hitam pada langit dan siluet nampak selaras dengan warna air laut yang berwarna merah ke orange refleksi dari matahari yang berwarna kuning keemasan. Sebagaimana dijelaskan oleh Kartika (2004) bahwa harmoni antara lain lahir karena keselarasan warna.

2. Paduan Kontras

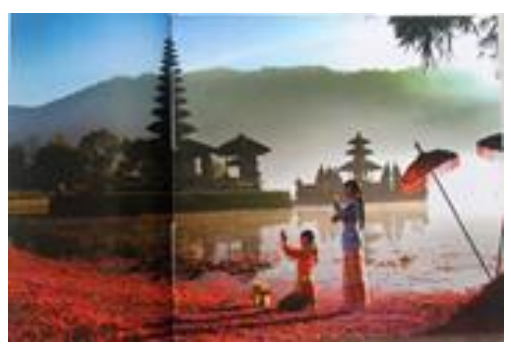

Gambar 14 "Sembahyang" (2006)

(Sumber : Jiwa Cahaya)

Dalam foto di atas menampilkan adanya paduan kontras, yaitu paduan kontras karena warna seperti yang terlihat pada payung dan bunga yang berguguran memiliki warna yang kontras atau lebih tajam dari unsur yang ada di dalam foto tersebut. Payung, pakaian dan bunga berwarna terang, kontras dengan warna pucat pada latar belakang yaitu pegun ungan, pura dan langit.

Gambar 15 “Aduh...Hampir Lepas” (2012)

(Sumber : Jiwa Cahaya)

Gambar 15 yang berjudul "Aduh...Hampir Lepas", terlihat empat orang perempuan sedang duduk berjejer dari kiri ke kanan yaitu, tiga remaja sedang berbincang mengenakan pakaian adat Bali dan seorang ibu mengenakan pakaian kebaya warna putih, gambar ini dilihat dari objek yang ditampilkannya, jelas tergolong dalam unsur paduan kontras karena warna dan paduan kontras karena ukuran. Kontras pada ibu yang mengenakan kebaya putih dengan remaja kebaya warnawarni. Kemudian jenis pakaian yang dikenakan ibu tersebut adalah kebaya dan remaja tersebut mengenakan pakaian penari. Sebagaimana dijelaskan oleh Kartika (2004) kontras terdiri dari kontras warna, ukuran, dan bentuk.

3. Paduan Irama (Repetisi)

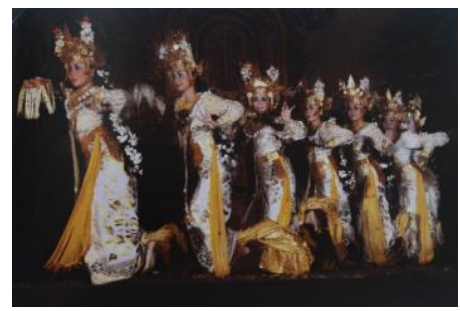

Gambar 16 “Legong Keraton Putih” (2011) 
(Sumber : Jiwa Cahaya)

Fotografi yang berjudul "Legong Keraton Putih", menurut penulis pada foto ini memperlihatkan paduan repetisi atau pengulangan pada beberapa unsur secara teratur dan terusmenerus. pada enam penari perempuan yang memakai pakaian yang sama, warna pakaian yang sama, aksesoris yang sama dan melakukan gerakan yang sama. Hal tersebut menunjukkan adanya bentuk pengulangan, yaitu pengulangan unsur bentuk dan peletakan unsur warna yang sama. Sebagaimana dijelaskan oleh Kartika (2004), irama muncul karena bentuk dan susunan teratur.

4.Paduan Gradasi (Harmonis menuju kontras)

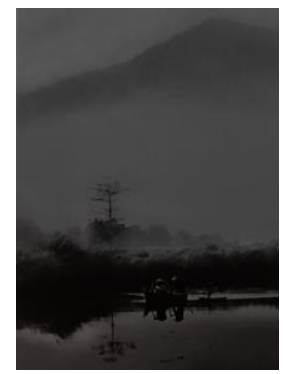

Gambar 17 "Melaut" (1978)

(Sumber : Jiwa Cahaya)

Karya di atas menunjukkan adanya unsur gradasi. Karena terlihat pada bagian atas atau puncak gunung sebagai latar berwarna gelap dan bagian bawah gunung berwarna terang. Selain itu pada danau terlihat juga adanya gradasi yaitu, bagian pinggir danau yang ditutupi rumput berwarna gelap sedangkan bagian tengah danau berwarna terang. Foto dengan teknik superimpose ini memperlihatkan peralihan nada warna secara perlahan-lahan dari hitam ke warna putih. Seperti yang dijelaskan oleh Kartika (2004), gradasi adalah peralihan nada dari gelap ke terang.

\section{c. Hukum Penyusunan (Azas Desain)}

Hukum penyusunan (azas desain) dibagi menjadi empat unsur yaitu, asas kesatuan, keseimbangan, kesederhanaan (simplicity), aksentuasi (emphasis), dan proporsi.

1. Asas Kesatuan (Unity)

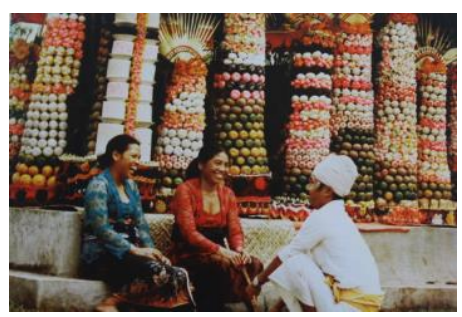

Gambar 18 "Kepalang Riang Tak Kepalang” (1984)

(Sumber : Jiwa Cahaya)

Karya foto di atas terdapat kesatuan antara unsur-unsur. Terlihat bahwa dua orang perempuan menggunakan pakaian adat sedang berdialog dengan seorang laki-laki. Ketiga orang tersebut saling berhadapan sehingga memberikan kesan satu bentuk yang utuh. Ini menunjukkan kesatuan seperti ditegaskan Kartika (2014). 
2. Keseimbangan (Balance)

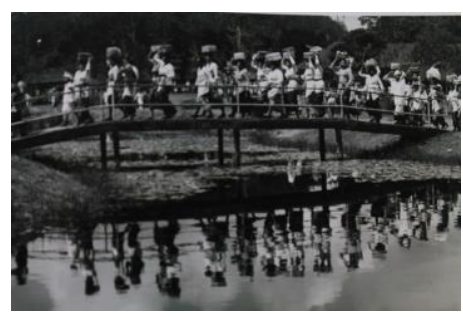

Gambar 19 "Refleksi" (2014)

(Sumber : Jiwa Cahaya)

Karya di atas memperlihatkan sekelompok ibu-ibu berjalan di atas jembatan yang dibawahnya terdapat sungai yang melahirkan refleksi. Hal tersebut menimbulkan adanya kesan seimbang secara visual bagian atas dan bagian bawah. Gambar 19 dengan judul "Refleksi" tergolong dalam unsur keseimbangan formal karena unsur-unsur yang ada dalam foto tersebut menghadirkan keseimbangan bentuk secara simetris atas dan bawah. Keseimbangan dapat diwujudkan melalui penyusunan unsur seni rupa yang simetris maupun asimetris. Sebagaimana dijelaskan oleh Kartika (2004).

\section{Simplicity (Kesederhanaan)}

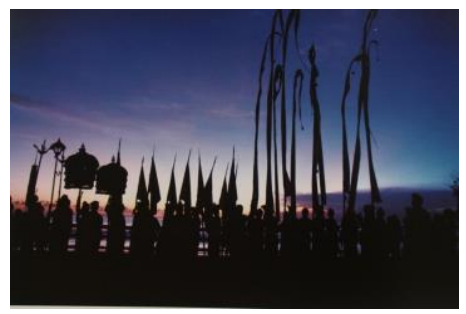

Gambar 20“Melasti di Pantai Kuta” (2010)

(Sumber : Jiwa Cahaya)

Gambar berikut memperlihatkan penerapan struktur yang sederhana, sesuai dengan pola, fungsi atau efek yang digunakan seperti pada latar belakang terlihat langit yang mulai gelap dan latar depan sekumpulan orang-orang yang sekaligus dijadikan objek utama dalam foto tersebut. Objek utama siluet, latar belakang terang bergradasi ke gelap. Oleh sebab itu gambar 20 dengan judul "Melasti di Pantai Kuta" dikategorikan dalam unsur kesederhanaan struktur. Sebagaimana dijelaskan oleh Kartika (2004).

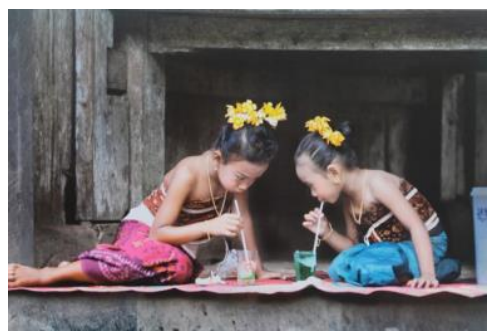

Gambar 21 "Minum Bersama" (2013)

(Sumber : Jiwa Cahaya)

Gambar 21 memperlihatkan penerapan teknik yang sederhana, komposisi yang dicapai menggunakan teknik yang sederhana, seperti pengaturan pose objek terlihat sederhana, pengambilan angel, pencahayaannya menggunakan cahaya alami atau sinar matahari langsung, dan menggunakan lensa standar. Oleh karenanya gambar 21 dengan judul "Minum Bersama" dikategorikan dalam unsur kesederhanaan teknik. Seperti yang dijelaskan oleh Kartika (2004) 


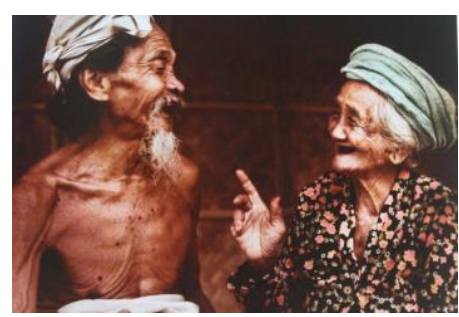

Gambar 22 "Rukun Sampai Tua” (1983)

(Sumber : Jiwa Cahaya)

Dan foto berikutnya "Rukun Sampai Tua" memperlihatkan penerapan kesederhanaan unsur. Unsur-unsur dicapai dengan sederhana tidak rumit, sehingga membentuk kesatuan, yakni unsur yang ada dalam foto tersebut terdapat seorang kakek dan seorang nenek yang sedang berdialong sambil tertawa. Dalam foto ini pengaturan objek yang terlihat sederhana, pengambilan angel menggunakan eye angel atau normal angel, pencahayaannya menggunakan cahaya alami langsung dan menggunakan lensa standar. Oleh sebab itu gambar 22 termasuk dalam kesederhanaan unsur. Sebagaimana dijelaskan oleh Kartika (2004).

4. Emphasis (Aksentuasi)

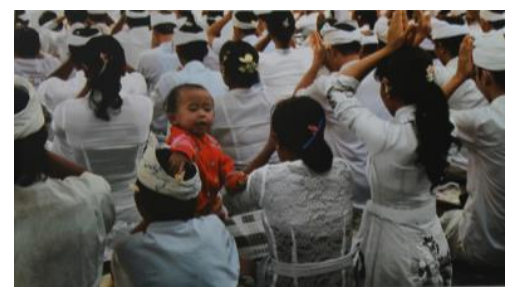

Gambar 23 “Usil” (2010)

(Sumber : Jiwa Cahaya)

Seorang anak kecil berada di tengah-tengah orang yang sedang melakukan upacara. Dalam foto anak tersebut menjadi center of interest karena menggunakan pakaian berwarna merah berbeda dengan yang lainnya yang menggunakan pakaian berwarna putih, menghadap ke belakang sementara yang lainnya menghadap ke depan. Karenanya gambar 23 termasuk dalam unsur aksentuasi melalui ukuran, kontras, dan susunan. Satu-satunya anak di tengah-tengah ibuibu. Sebagaimana dijelaskan oleh Kartika (2004).

5. Proporsi

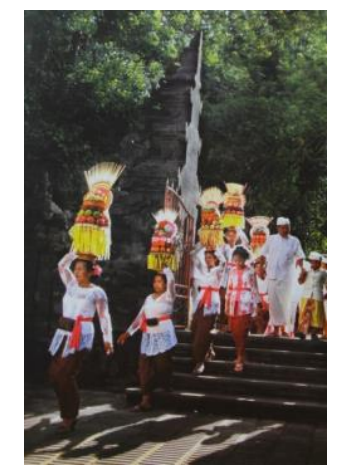

Gambar 24 "Menuju Jeroan Pura” (2010)

(Sumber : Jiwa Cahaya)

Pada gambar 24 "Menuju Jeroan Pura", terlihat ibu-ibu membawa keranjang yang akan melakukan upacara di pura. Dalam foto tersebut tidak ada perubahan bentuk atau ukuran objek 
dengan latar. Selain itu, perbandingan objek dengan objek lain tampak wajar, yaitu pada orang dengan gapura. Foto tersebut menggunakan lensa standar yang memungkinkan tidak terjadi distorsi. Sebagaimana dijelaskan oleh Kartika (2004).

\section{KESIM PULAN DAN SARAN}

\section{Kesimpulan}

Berdasarkan pembahasan yang telah dipaparkan dalam penelitian ini maka, dapat disimpulkan sebagai berikut.

Jenis-jenis fotografi yang ditekuni oleh Djaja Tjandra Kirana yang terdapat dalam buku "Jiwa Cahaya" adalah sebagai berikut: human interest (fotografi kehidupan manusia), photojournalism (fotografi jurnalistik), landscape photography (fotografi pemandangan), photography modelling (fotografi model), street photography (fotografi jalanan), dan portrait photography (fotografi potret).

Nilai estetika fotografi Djaja Tjandra Kirana yang terdapat dalam buku "Jiwa Cahaya" adalah sebagai berikut: unsur-unsur rupa (unsur desain) terdiri dari enam unsur yaitu, garis, shape (bangun), tekstur, warna, intensity/chroma, ruang dan waktu; dasar-dasar penyusunan (prinsip desain) terdiri dari empat unsur yaitu, paduan harmoni, paduan kontras, paduan irama, dan paduan gradasi, dan hukum penyusunan (azas desain) terdiri dari empat unsur yaitu, asas kesatuan, keseimbangan, simplicity (kesederhanaan), emphasis (aksentuasi), dan proporsi.

\section{Saran}

Dari penelitian ini, penulis sampaikan saran:

Bagi Peneliti Lain: diharapkan agar meneliti karya Djaja Tjandra Kirana yang ada di dalam buku "Jiwa Cahaya" ditinjau dari aspek lain, misalnya komposisi, teknik fotografi, dan lain -lain.

Bagi Pehobi Fotografi dengan penelitian ini diharapkan bisa menjadi referensi bagi pehobi fotografi untuk mengetahui jenis-jenis fotografi dan nilai estetika dalam karya fotografi. Bagi Undiksha: diharapkan agar penelitian ini dapat memperkaya kemungkinan penelitian estetika, khususnya estetika fotografi.

\section{DAFTAR PUSTAKA}

Giwanda, Griand. 2002. Panduan Praktis Foto Menarik. Bandung: Puspa Swara.

Kartika, Sony. 2004. Pengantar Estetika. Bandung: Rekayasa Sains

Hardiman, dkk. 2014. Jiwa Cahaya Djaja Tjandra Kirana. Denpasar: Rasi Cahya Gemilang

Sugiyono. 2007. Metode penelitian pendidikan. Bandung: Alfabeta

http://www.idseducation.com/articles/macam-macam-genre-fotografi, diakses pada tanggal 15 Oktober 2016, pukul 20.12 WITA

research dashboard.binus.ac.id/uploads/paper/.../72_DKV_Agnes\%20Paulina.pdf diakses pada tanggal 31 Januari 2017, pukul 19.25 WITA 